\title{
UPAYA MENCIPTAKAN WIRAUSAHA BARU MANDIRI BERBASIS IPTEKS DAN KEARIFAN LOKAL
}

\author{
Nasrul Rofiah Hidayati ${ }^{1)}$, Elva Nuraina ${ }^{2)}$, Isharijadi ${ }^{3)}$ \\ ${ }^{1)}$ FPMIPA, IKIP PGRI MADIUN \\ email: nasrul.rofiah@gmail.com \\ ${ }^{2)}$ FPIPS, IKIP PGRI MADIUN \\ email : elvanuraina99@gmail.com
}

\begin{abstract}
IKIP PGRI has always had a commitment to establish an independent mindset in students, for the students equipped with the adaptive ability of science, has leadership and entrepreneurial spirit. Therefore entrepreneurships spirit among the students for the sake of the next generation job creators need to be cultivated. The realization of this commitment IKIP PGRI Madison follow science and technology program for entrepreneurship (IBK) with the aim of developing human potential as young entrepreneurs, independent, based on local knowledge of the higher education and the establishment of outcome-based self-eleven new science and technology entrepreneurs who are ready to do business in community per year, the product of new entrepreneurial students have the advantage of science and technology, better known products produced by student entrepreneurs (PKMK) by the public, increasing the business management of students who have started businesses (oyster mushroom cultivation, the creation of a variety of zipper into a bag and wallet, Pecel Origiri and Yoghurt various flavors) and the publication of the results in the journal IBK entrepreneurship programs. The methods used to recruit participants Ibk tenants based on the success of the team in the delivery of new entrepreneurs Ibk independently in the first year. The number of tenants who started the business in the first year as many as 11 people were divided into 4 groups of businesses. Realization of IKIP PGRI Madison IBK program has accomplished $100 \%$. The work program has been implemented: Socialization, debriefing, internship, start up bussiness, implementation and monitoring of business activities on an ongoing basis by IBK Team PGRI Madison Teachers' Training College and a business center complete shop means the student as a student business center, workshop, final report. Pembinanaan process, directing, monitoring and evaluation of business activities will be carried out by a team of tenants and UPPK IBK (Training and Enterprise Development Unit) on a regular basis with the aim to give birth to new entrepreneurs in the IKIP PGRI student Madison as creator of employment generation.
\end{abstract}

Keywords: Entrepreneurial self, science and technology, Local Wisdom

\section{PENDAHULUAN}

Bangsa yang mandiri adalah bangsa yang memiliki banyak wirausahawan. Tidak dapat dipungkiri keberadaan para wirausahawan baik yang memiliki skala usaha kecil (UMKM), menengah maupun besar mampu berperan sebagai penggerak roda perekonomian bangsa. Oleh karena itu sudah saatnya peran perguruan tinggi lebih diarahkan pada pembentukan karakter yang kuat, mandiri memiliki jiwa kepemimpinan tinggi dan semangat kewirausahaan.

IKIP PGRI Madiun sebagai lembaga pendidikan tinggi yang selalu responsif dengan perkembangan terkini di masyarakat dan selalu berupaya untuk meningkatkan kualitas dan daya saing lulusan telah merancang strategi pendidikan yang ditujukan untuk menghasilkan sumber daya manusia yang berkualitas dan kompetitif secara global. Untuk itu IKIP PGRI
Madiun membekali mahasiswa dengan kemampuan keilmuan adaptif yang dapat dikembangkan sesuai dengan kebutuhan perubahan ilmu pengetahuan dan teknologi. Lulusan perguruan tinggi harus memiliki karakter yang kuat, mandiri memiliki jiwa kepemimpinan dan semangat kewirausahaan yang tinggi.

Dalam upaya menumbuh kembangkan jiwa kewirausahaan, IKIP PGRI Madiun telah membekali mahasiswa dengan mewajibkan mahasiswa mengikuti mata kuliah kewirausahaan. Proses perkuliahan kewirausahaan dirancang dengan memberikan tugas pada mahasiswa dengan mewajibkan mahasiswa merancang bussiness plan dan merealisasikannya dalam suatu kegiatan usaha.

Upaya lainnya dilakukan lembaga melalui pemberian motivasi pada mahasiswa untuk mengembangkan kreatifitas melalui kegiatan 
PKM-K. Jumlah PKM tahun 2012 yang lolos didanai dikti sebanyak 58 proposal, dimana 19 proposal diantaranya merupakan PKM-K. Mahasiswa PKM-K yang memiliki minat untuk merintis dan mengembangkan usahanya secara berkesinambungan sejumlah 4 kelompok.

Ipteks bagi Kewirausahaan (IbK) merupakan suatu program yang mewadahi mahasiswa PKM-K maupun PKM jenis lainnya untuk merealisasikan kreatifitas mahasiswa menjadi suatu usaha yang dilaksanakan secara berkesinambungan. Melalui program IbK, Direktorat Jendral Pendidikan Tinggi dan IKIP PGRI Madiun berupaya untuk mengembangkan kreatifitas dan merealisasikannya dalam suatu bisnis dengan skala kecil dengan tujuan untuk menciptakan wirausahawa baru yang berbasis Ipteks dan kearifan lokal.

\section{METODE PELAKSANAAN PROGRAM}

Metode pendekatan IbK yang akan dilaksanakan melalui prosedur sebagai berikut :

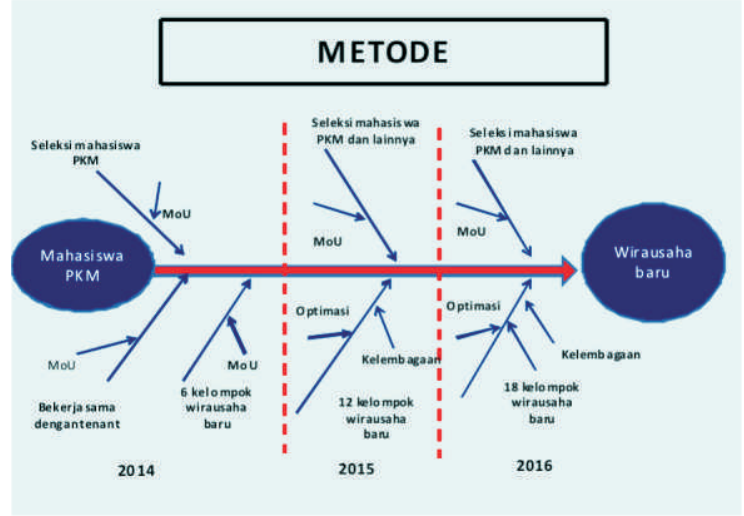

Metode pendekatan IbK yang akan dilaksanakan melalui prosedur sebagai berikut :

a. Menggali informasi beberapa mahasiswa yang telah merintis usaha.

b. Koordinasi dengan wakil rektor III yang mewadahi kegiatan PKM dan meminta daftar mahasiswa PKMK yang lolos didanai Dikti tahun 2012.

c. Memilih mahasiswa yang telah merintis usaha berdasarkan komitmennya yang kuat untuk melaksanakan kegiatan usaha secara berkesinambungan.

d. Memilih mahasiswa PKMK yang akan diikutsertakan dalam program IbK berdasarkan komitmen yang kuat untuk memulai usaha.

e. Menghubungi Nara Sumber dan mitra yang telah mapan dan sukses berwirausaha untuk memberikan pelatihan kewirausahaan.

f. Magang pada industri mitra selama 1 bulan. g. Pembimbingan secara intensif dari tim pelaksana IbK.

h. Pengawasan secara intensif oleh tim pelaksana IbK dan UPPK.

i. Pemberian bantuan biaya modal awal bagi para tenant yang berasal dari mahasiswa PKMK yang memiliki komitmen memulai kegiatan usaha berdasarkan rencana bisnisnya.

j. Pemberian bantuan tambahan modal pada mahasiswa yang telah merintis usahanya.

k. Pemberian bantuan solusi oleh Tim dari UPPK jika ada masalah yang dihadapi para tenant.

\section{HASIL DAN PEMBAHASAN}

Realisasi program IbK di IKIP PGRI Madiun telah dilaksanakan sesuai dengan rencana yang telah disusun. Prosentase pencapaian program IbK IKIP PGRI Madiun sampai dengan saat ini adalah $100 \%$. Beberapa tahapan yang telah dilaksanakan adalah:

a. Sosialisasi Program IbK

Adanya program IbK disosialisasikan oleh tim IbK IKIP PGRI Madiun pada mahasiswa penerima hibah PKM baik PKMK maupun PKM lainnya pada tanggal 29 Maret 2014.

b. Pembekalan

Sebelum merealisasikan usahanya mahasiswa diberikan pembekalan seputar pengelolaan UKM oleh Pemilik dan Pimpinan PT Elang Persada dan CV Sigma yaitu Bapak Bambang Kamahayanikan, SE dan dari ketua pelaksana IbK ibu Nasrul Rofiah Hidayati, S.T., M.Pd pada tanggal 5 April 2014. Pembekalan ini diikuti oleh 18 mahasiswa pelaksana IbK, dosen pelaksana $\mathrm{IbK}$ dan juga wakil dari beberapa UKM mitra.

c. Magang

Proses magang dilaksanakan selama 2 minggu di 5 perusahaan mitra yaitu : PT Elang Persada, CV Sigma, Perusahaan Roti Bolu Fajar, Anggi Bordir dan Perusahaan kerupuk Puli" lempeng".

d. Start up Bisnis

Kegiatan memulai usaha dilaksanakan oleh kelompok mahasiswa pada peserta IbK pada tanggal 25 April 2014. Tiap-tiap kelompok bisnis mahasiswa mendapatkan pinjaman modal dari pelaksana IbK melalui dana hibah IbK dari Dirjen DIKTI Kemdikbud dengan waktu pengembalian yang lunak.

e. Melengkapi fasilitas ruko 
Setelah bisnis mahasiswa berjalan dan dengan pantauan dan bimbingan dari dosen pendamping dari tim IbK maka bisnis mahasiswa dilaksanakan tersentral $\mathrm{d}$ ruko pusat bisnis mahasiswa "EQUITY". Persiapan fasilitas ruko antara lain tim pelaksana membeli Neon box, banner, freezer, kulkas, kompor gas tabung, selang kompor, meja, kursi, rak, AC dsb.

f. Realisasi Kegiatan bisnis di Pusat Bisnis Mahasiswa

Bisnis mahasiswa sudah tersentral di ruko Pusat Bisnis Mahasiswa "EQUITY". Kegiatan berjalan lancar dengan konsumen paling dominan adalah dari warga kampus.Kegiatan rapat-rapat di kampus sering memesan konsumsi dari “"EQUITY”.

g. Sarasehan

Sarasehan dilaksanakan 2 kali pada tanggal 3 September 2014 untuk mdan 8 November 2014

h. Monev internal

Monev internal dilaksanakan pada tanggal 21 Agustus 2014 dengan reviewer Prof.Dr. Sarwiji Suwandi, M.Pd ( dari UNS ) dan Prof.Dr. Abdul Gafur Daniamiseno, M.Sc dari UNY

i. Monev Eksternal

Monev eksternal dikti dengan reviewer Dr. Putu dilaksanakan 2 tahap yaitu tahap I : Pemaparan hasil kegiatan yang dilakukan di Universitas Muhammadiyah Surakarta (Solo) dan tahap II : Monev lapangan d IKIP PGRI Madiun.

j. Publikasi di jurnal kewirausahaan

Publikasi dilakukan di jurnal kewirausahaan prodi akuntansi IKIP PGRI Madiun "Asset" ( masih dalam daftar tunggu).

Dari 7 kelompok usaha yang telah direkrut pada program IbK tahun 2013, sebanyak 4 kelompok dengan keseluruhan jumlah tenant sebanyak 11 orang telah menjadi wirausaha. Sampai dengan saat ini 11 tenant tersebut telah melaksanakan kegiatan usaha secara berkelanjutan dan perkembangan usahanya cukup memuaskan. 4 kelompok usaha tersebut dapat dilihat pada Tabel 1 sebagaiberikut:

\begin{tabular}{|l|l|l|l|}
\hline No & Ketua & $\begin{array}{c}\text { Bidang } \\
\text { usaha }\end{array}$ & Perkembangan usaha \\
\hline 1 & $\begin{array}{l}\text { M. } \\
\text { David }\end{array}$ & $\begin{array}{l}\text { Budidaya } \\
\text { Jamur } \\
\text { Tiram }\end{array}$ & $\begin{array}{l}\text { Rata-rata Omzet per } \\
\text { bulan Rp 1.400.000 } \\
\text { dan rata -rata laba per } \\
\text { bulan Rp 1.000.000 }\end{array}$ \\
\hline
\end{tabular}

\begin{tabular}{|l|l|l|l|}
\hline 2 & Fat'u & Kreasi \\
Laili & retsleting & $\begin{array}{l}\text { Selama April - } \\
\text { September Total } \\
\text { penjualan }=\text { Rp } \\
5.938 .000 . \text { dan total } \\
\text { laba Rp 1.669.750 }\end{array}$ \\
\hline 3 & $\begin{array}{l}\text { Lingga } \\
\text { Caraka }\end{array}$ & $\begin{array}{l}\text { (PERI/Pe } \\
\text { cel } \\
\text { Origiri) }\end{array}$ & $\begin{array}{l}\text { Produksi berdasarkan } \\
\text { pesanan. Perolehan } \\
\text { laba bersih sampai } \\
\text { dengan saat ini Rp } \\
1.045 .630\end{array}$ \\
\hline 4 & $\begin{array}{l}\text { Devi } \\
\text { Ratna } \\
\text { Sari }\end{array}$ & $\begin{array}{l}\text { Yogurt } \\
\text { aneka } \\
\text { rasa }\end{array}$ & $\begin{array}{l}\text { Total perolehan laba } \\
\text { selama 6 kali produksi } \\
\text { adalah Rp 1.556.000 }\end{array}$ \\
\hline
\end{tabular}

Tabel 1. Data tentang yang melanjutnya usahanya

Tenant yang telah berwirausaha akan terus mendapat bimbingan dan arahan dari Tim $\mathrm{IbK}$ dan perkembangan usahanya terus menerus dievaluasi dan dipantau secara berkesinambungan. Tim Ibk memberikan bantuan pula berupa pinjaman modal untuk meningkatkan skala usaha para tenant agar para tenant bisa menjadi seorang wirausaha yang mandiri dan terampil dalam mengelola usaha dengan skala usaha yang lebih besar dari sebelumnya.

Hasil yang dicapai pada tahun I program IBK di IKIP PGRI Madiun adalah dihasilkannya produk dari mahasiswa yang telah merintis usaha baru memiliki potensi dan nilai ekonomi yang bagus. Perkembangan usaha mahasiswa yang telah berwirausaha cukup bagus dan pemasarannya mulai meluas ke wilayah di luar Karesidenan Madiun bahkan ada yang sudah mencapai wilayah Kalimantan.

Kreasi retsleting menjadi tas, dompet dan lain-lain termasuk produk yang banyak digemari kalangan muda maupun tua, bahkan pemasarannya sudah mencapai wilayah Kalimantan. Omzet per bulannya rata-rata Rp 1.000.000. Mahasiswa memiliki 1 orang pekerja (penjahit), jadi kelompok mahasiswa ini sudah bisa menciptakan lapangan kerja bagi masyarakat sekitar tempat tinggalnya.

Budidaya jamur tiram merupakan usaha mahasiswa yang memiliki prospek bisnis yang bagus. Mahasiswa mampu memasok jamur untuk para pedagang di wilayah Ponorogo dan sekitarnya setiap hari. Produksi baglog telah dilakukan selama 4 periode ( $\mathrm{Rp} \mathrm{10.000.000).}$ Laba bersih yang diperoleh sampai dengan saat 
ini (selama 4 bulan) Rp 5.715.000. Saat ini mahasiswa mendapatkan order dari dinas pertanian untuk memasok sebanyak 40.000 baglog.

Pecel Origiri merupakan makanan khas Madiun ala Jepang yang dijual berdasarkan pesanan. Beberapa event di wilayah Madiun kerap kali memesan pecel origir. Yoghurt aneka rasa merupakan suatu produk yang dijual secara konsinyasi di beberapa tempat. Produk tersebut digemari anak-anak karena cita rasanya yang enak. Berikut adalah beberapa dokumentasi kegiatan program IbK di IKIP PGRI Madiun :

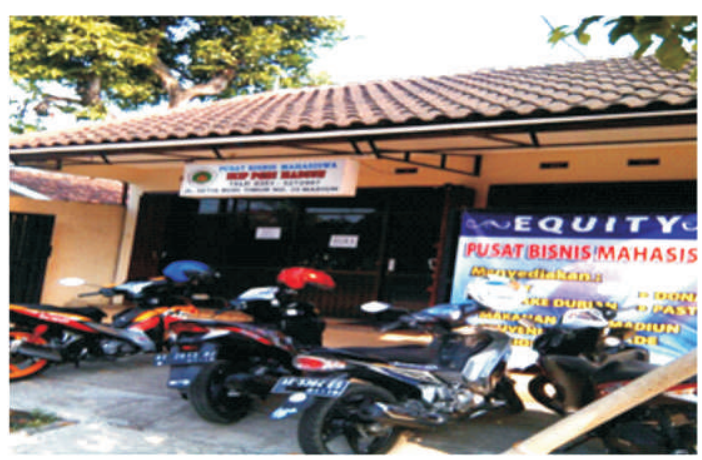

Gambar 1.

Pusat Bisnis Mahasiswa "EQUITY"

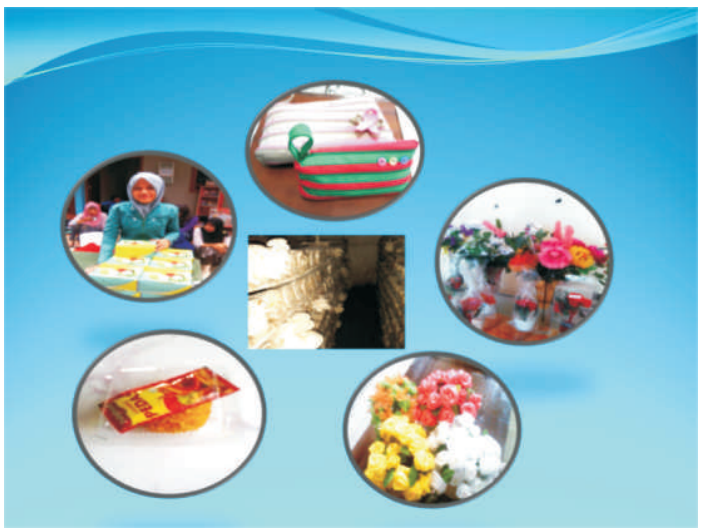

Gambar 2.

Produk tenant

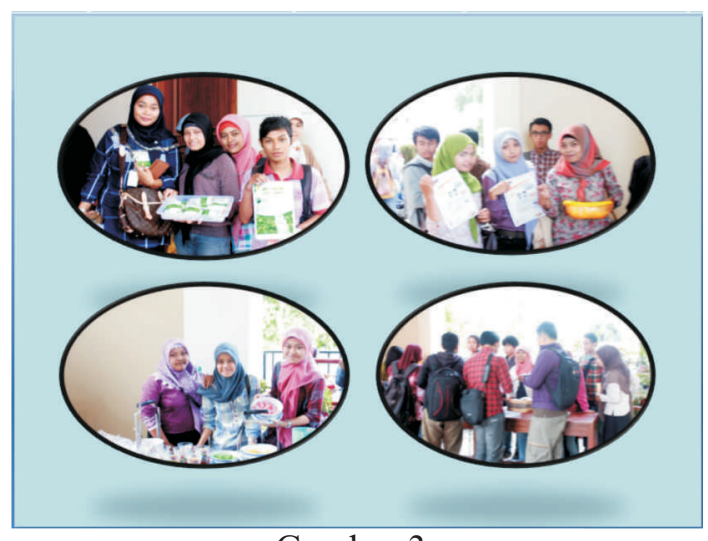

Gambar 3.

Bazar kewirausahaan

\section{KESIMPULAN}

Berdasarkan perkembangan usaha kelompok mahasiswa pada program IbK dapat disimpulkan:

a. Realisasi pencapaian program IbK IKIP PGRI Madiun telah terlaksana $100 \%$.

b. Mahasiswa yang tidak memiliki komitmen melanjutkan kegiatan usaha sebanyak 3 kelompok dan 4 kelompok baru yang berkomitmen melaksanakan usaha secara berkesinambungan dan mandiri, rata-rata jumlah mahasiswa per kelompok ada 2-3 orang, jadi total mahasiswa yang mengikuti program IbK dan telah menjadi wirausaha baru mandiri pada tahun pertama sebanyak 11 orang.

c. Progrm IbK dapat mewadahi Kelompok mahasiswa IKIP PGRI Madiun yang memiliki komitmen berwirausaha. Melalui program IbK Mahasiswa mengalami proses pembelajaran kewirausahaan secara nyata melalui kreatifitas bisnis mereka.

d. Melalui program IbK dapat dilihat kadar komitmen berbisnis mahasiswa, terbukti dengan adanya kelompok yang melanjutkan dan tidak melanjutkan kegiatan usahanya. Hal ini menunjukkan memiliki atau tidak memilikinya jiwa wirausaha masing-masing mahasiswa yang mengikuti program IbK.

\section{REFERENSI}

Wiratmo, M. Pengantar Kewirausahaan Kerangka Dasar Memasuki Dunia Bisnis edisi pertama. BPFE Yogyakarta. Yogyakarta. 2001.

Inwood, D dan Jean Hammond, Pengembangan produk. PT Pustaka Binaman Pressindo, 1995

Modul kewirausahaan bank mandiri tahun 2009

Handout kewirausahaan. 